\title{
Efektivitas Virtual Classroom dan Flip the Teacher dalam Flipped Classroom pada Chuukyuu Bunpou
}

\author{
${ }^{1}$ Aulia Istianingrum, ${ }^{2}$ Rita Agustina Karnawati \\ Universitas Muhammadiyah Prof. DR. HAMKA, Indonesia \\ 1auliaistia@gmail.com \\ 2rita_japanese@yahoo.com
}

DOI: $10.18196 /$ jjlel.4238

\begin{abstract}
Abstrak
Penelitian ini menganalisis efektivitas dan perbedaan efektivitas Virtual Classroom dan Flip the Teacher dari metode Flipped Classroom dalam Chuukyuu Bunpou pada mahasiswa semester IV Pendidikan Bahasa Jepang Universitas Muhammadiyah Prof.DR. HAMKA HAMKA 2019-2020 menggunakan eksperimen murni pre-test post-test 2 grup. Sampel terdiri dari 19 responden di kelas $4 A$ dan 17 responden di kelas 4B. Hasil nilai Sig. (2 tailed) uji tantara Virtual Classroom dan Flip the Teacher, yaitu 0,207 lebih tinggi dari taraf signifikansi. Sehingga tidak ada yang signifikan antara perbedaan peningkatan hasil belajar siswa yang menggunakan Virtual Classroom dan Flip the Teacher. Dari hasil tes normalized gain di kedua kelas, skor normalized gain untuk teknik Virtual Classroom adalah 0,49 dan skor normalized gain untuk teknik Flip the Teacher sebesar 0,34 sehingga keduanya memiliki tingkat efektivitas yang sedang. Persentase gain ternormalisasi untuk Virtual Classroom pada kelas eksperimen 1 adalah 49,50\% sementara Flip the Teacher pada kelas eksperimen 2 adalah 33,86\%. Dapat disimpulkan bahwa persentase efektivitas Virtual Classroom lebih besar daripada Flip the Teacher dalam peningkatan hasil belajar mata kuliah Chuukyuu Bunpou pada mahasiswa semester IV Pendidikan Bahasa Jepang UHAMKA tahun 2019-2020.
\end{abstract}

Kata kunci: metodologi; bunpou; flipped classroom

\footnotetext{
Abstract

(The Effectiveness of Virtual Flipped Classroom and Flip the Teacher in the Chuukyuu Bunpou) This research analyzes the effectiveness and the differences in the effective techniques of virtual classrooms and flip the teacher from the flipped classroom in the chuukyuu bunpou. This study was conducted in the fourth-semester students of Japanese Language Education, Muhammadiyah Prof. DR. HAMKA University 2019-2020. The method for this research used an actual
} 
experiment with a pre-test post-test two-group design. The sample consisted of 19 respondents in class $4 A$, which applied virtual classroom and 17 respondents in class 4B, which applied flip the teacher concept. T-test results between the virtual classroom and flip the teacher gained Sig. (2 tailed) point 0.207. There was no significant difference in the learning outcomes between using a virtual classroom and flip the teacher. Based on the normalized gain test results in both classes, the normalized gain score for the virtual classroom was 0.49, while the normalized gain score for flip the teacher was 0.34; thus, both have moderate effectiveness. The percentage of normalized gain for the virtual classroom was 49.50\% while flip the teacher was 33.86\%. It can be concluded that the effectiveness of the virtual classroom was greater than flip the teacher in the chuukyuu bunpou.

Keywords: bunpou; flipped classroom; method

\section{PENDAHULUAN}

Dalam mempelajari bahasa asing, tentu saja hal yang diharapkan oleh pembelajar adalah mampu berkomunikasi dengan baik. Menurut Septianingsih dan Karnawati, setiap individu dalam berkomukasi memiliki dua tuntutan kemampuan yaitu kemampuan dalam lisan ataupun kemampuan dalam tulisan (Septianingsih \& Karnawati, 2019). Kemampuan tersebut sangat berhubungan erat dengan tata bahasa. Menurut Agustin, seseorang yang jika tidak hanya menguasai kosakata bahasa tersebut, namun juga struktur atau tata bahasanya dalam berbahasa dapat dikatakan mahir (Agustin, 2015). Sehingga agar mampu berkomunikasi dengan baik, pentingnya penggunaan tata bahasa yang tepat agar dapat tersampaikan dengan baik maksud dari yang disampaikan oleh pembicara.

Tata bahasa sendiri termasuk studi tentang sintaks (urutan kata), struktur klausa dan frasa, dan klasifikasi bagian-bagian ujaran (misalnya kata benda, kata kerja, predikat, klausa, dll). Keduanya dapat berupa deskriptif mengenai pola kalimat, juga dapat berupa generatif atau pun transformatif. Aturan ini dapat menghasilkan kalimat yang dapat diterima secara tata bahasa (transformasi dari aturan dasar menjadi kalimat aktual) (Andrews et al., 2006). Hakikatnya pengetahuan dan kemampuan tata bahasa merupakan bagian dari kemampuan berbahasa dalam menyajikan kalimat hingga dapat diterima, baik 
dalam bentuk artikel, karangan dan lain sebagainya. Kemampuan berbahasa melibatkan semua aspek ketatabahasaan seperti klasifikasi kata maupun linguistik secara umumnya. Sehingga penting memahami dan mengerti tata bahasa suatu bahasa yang menjadi kunci pemahaman seluruh aspek berbahasa.

Dalam pembelajaran bahasa Jepang, penggunaan tata bahasa disebut dengan Bunpou. Chuиkyu bunpou merupakan tingkat kemahiran tata bahasa dalam tingkat intermediate atau menengah. Dalam pembelajaran bunpou, kesulitan menghafal tata bahasa ini sering dialami oleh pembelajar bahasa Jepang, selain karena pola kalimat yang banyak, sering juga ditemukan arti dari tata bahasa yang sama namun memiliki makna yang berbeda. Kesulitan ini akan berpengaruh pada kemampuan yang lain seperti menulis, berbicara, mendengarkan dan membaca. Sehingga diperlukan metode yang sesuai dengan kebutuhan tersebut.

Metode pembelajaran yang kini tengah gencar diaplikasikan adalah flipped classroom yang merupakan bagian dari active learning. Menurut Rindaningsih, pembelajaran dengan flipped classroom adalah pembelajaran dimana dalam mendapatkan materi belajar, siswa bertanggung jawab untuk mendapatkan secara mandiri melalui online. Flipped classroom juga dapat meningkatkan motivasi belajar dan memaksimalkan keberhasilan pembelajaran (Rindaningsih, 2018). Pembelajaran dengan metode ini yaitu dengan membalikkan prosedur pengajaran tradisional dan menggunakan video pengajaran online untuk menyampaikan konten pengajaran. Video instruksional akan memberi siswa kemampuan untuk bertanggung jawab atas pembelajaran mereka. (Pavanelli, 2018). Flipped classroom diterapkan dalam bentuk active learning, dengan saling berhubungan dengan siswa, menggunakan hybrid course (penggunaan teknologi dengan menerapkan element pembelajaran seperti yang dilakukan dengan cara konvensional) dan podcasting. Dalam flipped classroom, instruktur membuat video pembelajaran, screencast ataupun podcast dan sebagainya yang akan diajarkan kepada siswa 
diluar kegiatan akademik dalam kelas, dan menggunakan dengan sebaik baiknya waktu pada kelas pembelajaran untuk lebih berhubungan dengan siswa melalui aktifitas kolaborasi yang difasilitasi oleh instruktur (Milman, 2012). Pembelajaran menggunakan flipped classroom memiliki keuntungan berupa mempromosikan kemampuan belajar tim, dan model pembelajaran yang lebih berorientasi pada masa depan (Sojayapan \& Khlaisang, 2018). Dalam penggunaan flipped classroom sendiri, terdapat alternatif penerapan yaitu virtual classroom dan flip the teacher.

Virtual classroom pada flipped classroom atau yang disebut juga dengan virtual flipped classroom memungkinkan siswa menonton dan mendengarkan guru di rumah dan menampilkan interaksi dan pengetahuan keduanya dalam virtual classroom yang telah di sinkronisasikan dengan cara yang sama seperti pembelajaran di kelas sungguhan (Ismail \& Abdulla, 2019). Dalam penerapan virtual classroom pada flipped classroom, guru memberikan materi pembelajaran jauh lebih awal dari hari pembelajaran kelas.

Menurut Rochmah dan Majid (2018), penerapan virtual classroom dapat menggunakan media seperti media sosial (social network). Media sosial merupakan sebuah media yang didalamnya dapat digunakan untuk interaksi sosial antar individu maupun hubungan interpersonal dari pengguna satu dengan pengguna lain. Media sosial menghadirkan kemudahan bagi pengguna untuk dapat saling berhubungan antar pengguna melalui chat maupun pesan yang berupa gambar, suara atau audio, dan video serta saling memberikan informasi. Penggunaan media sosial juga dapat meningkatkan hubungan interpersonal pengguna serta menjadi fasilitas dalam berkomunikasi dalam berbagai jarak. Sehingga media sosial dapat dimanfaatkan untuk media pembelajaran. Media sosial yang dapat dimanfaatkan untuk pembelajaran disebut dengan social learning network atau media sosial pembelajaran. Interaksi yang terjadi dalam social learning network biasanya dilakukan dalam bentuk grup sehingga dapat digunakan untuk memonitor perkembangan kompetensi siswa, namun dapat juga dilakukan dalam bentuk individu. 
(Rochmah \& Majid, 2018). Pembelajaran aktif menggunakan Virtual classroom memungkinkan pembelajar untuk meningkatkan keterampilan kritis, terutama kemampuan untuk menerapkan penalaran analitis. Guru dapat menerapkan tugas yang menggunakan pemikiran kritis dalam proses pengajaran untuk meningkatkan kemampuan peserta didik dalam virtual classroom (Amornchai, Songkhla, \& Sujiva, 2015).

Sedangkan flip the teacher sering disebut juga dengan peer tutoring dimana siswa menjadi guru bagi siswa lain, dan guru sebagai fasilitator saja. Pasangan siswa dapat bekerja pada keterampilan akademik, sosial, perilaku, fungsional atau bahkan sosial. Ada banyak cara berbeda untuk memasangkan siswa, seperti berdasarkan tingkat kemampuan, keterampilan yang dikuasai, atau usia (Kapil \& Malini, 2018). Penggunaan flip the teacher pada flipped classroom tentu menuntut siswa menggunakan teknologi yang saat ini ada seperti mengakses informasi, dan dalam pembuatan materi itu sendiri seperti powerpoint, video editor, podcast dan sebagainya. Teknologi dapat menawarkan berbagai cara yang memotivasi belajar siswa dan dapat mereka kendalikan penggunaannya serta dapat meningkatkan kemampuan evaluasi diri (Patten \& Craig, 2007). Teknologi juga menawarkan lebih banyak kebebasan dan fleksibilitas bagi pelajar untuk belajar dengan mengakses informasi kapanpun dan berapa lamapun dengan cara yang berbeda (Lai \& Kritsonis, 2006). Peer tutoring pada flipped classroom, mengharuskan siswa memanfaatkan teknologi untuk mendapatkan informasi sebanyak banyaknya melalui berbagai media. Tutor dari siswa pada flip the teacher akan menyediakan materi sebagaimana layaknya seorang guru pada flipped classroom, mereka akan mengirim materi sebelum hari pembelajaran sehingga baik pemateri maupun teman yang diberi pengajaran akan lebih matang pada saat diskusi. Tutor dari teman ini akan membantu teman lain memahami materi serta memperbanyak diskusi antar siswa. Guru berperan sebagai fasilitator dimana mengoreksi kesalahan tutor dari siswa maupun membantu jalannya diskusi. 
Penerapan peer tutoring dalam flipped classroom yaitu siswa menonton video dan mendengarkan podcast atau membuat sendiri konten dari buku teks. Semua siswa diharuskan menonton video dan podcast di rumah atau di kampus sebelum kelas setiap minggu. Siswa secara sukarela mengajukan diri untuk mengajarkan pelajaran tentang bab pilihan yang dipilih dari buku teks dan video serta podcast yang diperlukan yang menyertai setiap bab. Keadaan siswa yang kadang mudah bosan pada saat proses pembelajaran. Flip the teacher ini dapat dijadikan salah satu alternatif pembelajaran. Dalam flip the teacher, siswa mungkin termotivasi oleh interaksi antar siswa yang terjadi sepanjang semester, memberikan kesempatan belajar bagi siswa kapan saja dan dimana saja, serta keinginan untuk kelas yang berpusat pada siswa (student-centered classroom), kemauan untuk menggunakan teknologi untuk meningkatkan pengajaran dan pembelajaran, atau termotivasi oleh keinginan mencoba sesuatu yang baru. Penerapan peer tutoring atau Flip the Teacher dapat menunjukkan hasil bahwa pelajaran flipped yang diajarkan oleh siswa bersifat interaktif dan menyenangkan, dan siswa menjadi lebih produktif dan antusias dalam kelas. (Graziano, 2017). Peer tutoring memberikan hasil yang positif untuk meningkatkan prestasi akademik yaitu meningkatnya nilai terutama bagi siswa yang menjadi tutor bagi temannya (Comfort \& James McMahon, 2014).

Untuk menemukan alternatif metode pengajaran yang efektif pada pembelajaran chuиkyuи bunрou maka berdasarkan penjabaran penerapan dan manfaat penggunaan virtual classroom dan flip the teacher dalam pembelajaran, peneliti melakukan penelitian untuk mengetahui efektifitas virtual classroom dan flip the teacher serta perbandingan keefektifan dari virtual classroom dan flip the teacher dalam flipped classroom pada mata kuliah chuukyuu bunpou atau tata bahasa Bahasa Jepang . 


\section{METODE PENELITIAN}

Bentuk penelitian yang digunakan adalah eksperimen murni dan desain pre-test post-test dua grup melalui pendekatan kuantitatif asosiatif dimana menyelidiki hubungan antara 2 variabel atau lebih serta teknik korelasi sederhana untuk mencari hubungan antar variabel (X1 terhadap Y dan X2 terhadap Y). Kemudian menentukan manakah yang lebih efektif diantara X1 dan X2 dan pengaruhnya terhadap Y dengan menggunakan dua kelas eksperimen. Sample berupa mahasiswa semester 4 Pendidikan Bahasa Jepang Universitas Muhammadiyah Prof. DR. HAMKA, kelas 4A dengan 19 responden akan diberi perlakukan dengan virtual classroom (X1) dan kelas 4B dengan 17 responden akan diberi perlakuan dengan flip the teacher (X2). Pembelajaran flipped classroom dengan kedua perlakuan yang berbeda digunakan media sosial berupa grup whatsapp.

Penelitian ini dilakukan dengan empat kali pertemuan dengan kelas eksperimen, serta pengujian pre-test dan post-test masing masing satu kali. Pengumpulan data dengan hasil penilaian pre-test dan post-test dan dianalisis dengan pengujian data yang dilakukan pada SPSS Statistic 25 mulai dari uji normalitas, uji homogenitas uji-t, dan uji gain ternormalisasi untuk mengetahui besar ataupun persentase kenaikan atau penurunan hasil belajar (efektivitas).

\section{HASIL DAN PEMBAHASAN}

\section{Analisis Deskriptif}

Data variabel bebas yaitu virtual classroom (X1) dan flip the teacher (X2) serta dengan variabel terikat yaitu chuukyuu bunpou (Y). Pengujian deskriptif ini menggunakan SPSS Statistics 25 dan berfungsi untuk mengetahui nilai minimum, maksimum, range, dan rata-rata (mean) hasil belajar setiap kelas eksperimen untuk mengetahui apakah nilai hasil belajar mengalami kenaikan, penurunan atau tetap. 


\begin{tabular}{|c|c|c|c|c|c|c|c|}
\hline \multicolumn{8}{|c|}{ Descriptive Statistics } \\
\hline & $\mathrm{N}$ & Range & Minimum & Maximum & Sum & Mean & $\begin{array}{l}\text { Std. } \\
\text { Deviation }\end{array}$ \\
\hline Nilai Pretest & 19 & 66 & 28 & 94 & 1141 & 60.05 & 16.952 \\
\hline Nilai Post Test & 19 & 49 & 51 & 100 & 1496 & 78.74 & 16.888 \\
\hline $\begin{array}{ll}\text { Valid } & \mathrm{N} \\
\text { (listwise) } & \\
\end{array}$ & 19 & & & & & & \\
\hline
\end{tabular}

Tabel 1. Statistik Deskriptif Kelas 4A

Pada tabel 1, nilai pre-test memiliki rata-rata sebesar 60.05 sedangkan post-test 78.74 pada kelas 4A. Hasil dari statistik deskriptif kelas 4A menunjukkan adanya kenaikan nilai sesudah diterapkan virtual classroom.

\begin{tabular}{|c|c|c|c|c|c|c|c|}
\hline \multicolumn{8}{|c|}{ Descriptive Statistics } \\
\hline & $\mathrm{N}$ & Range & Minimum & Maximum & Sum & Mean & $\begin{array}{l}\text { Std. } \\
\text { Deviation }\end{array}$ \\
\hline Nilai Pretest & 17 & 58 & 31 & 89 & 1168 & 68.71 & 18.020 \\
\hline Nilai Posttest & 17 & 35 & 63 & 98 & 1395 & 82.06 & 10.721 \\
\hline $\begin{array}{ll}\text { Valid } & N \\
\text { (listwise) } & \end{array}$ & 17 & & & & & & \\
\hline
\end{tabular}

Tabel 2. Statistik Deskriptif Kelas 4B

Pada tabel 2, nilai pre-test memiliki rata rata sebesar 68.71 sedangkan post-test 82.06 pada kelas 4B. Hasil statistik desktiptif kelas 4A menunjukkan adanya kenaikan sesudah diterapkan flip the teacher.

Setelah dilakukan analisis deskriptif, berdasarkan nilai mean pre-test dan post-test kelas 4A maupun kelas 4B mengalami kenaikan setelah diterapkan virtual classroom dan flip the teacher menggunakan flipped classroom.

a. Pengujian persyaratan data

a) Uji Normalitas

Untuk menentukan apakah data parametrik atau non parametrik dan menentukan jenis uji yang digunakan pada uji selanjutnya maka digunakan uji normalitas. Menurut Sundayana (2018), pada uji normalitas, data dengan nilai 
sig. lebih tinggi dari taraf signifikansi (0.01 atau 0.05) artinya berdistribusi normal sehsingga data bersifat parametrik. Pengujian t pada data ini sejumlah 36 buah dengan taraf signifikansi 0,05 maka digunakan Shapiro Wilk.

\begin{tabular}{lccc}
\multicolumn{4}{c}{ Sests of Normality } \\
& \multicolumn{3}{c}{ Shapiro-Wilk } \\
& Statistic & df & Sig. \\
\hline nilai_pretest_4A &, 958 & 19 &, 537 \\
nilai_postest_4A &, 910 & 19 &, 074 \\
nilai_pretest_4B &, 912 & 17 &, 106 \\
nilai_postest_4B &, 954 & 17 &, 527 \\
\hline
\end{tabular}

Tabel 3. Uji Normalitas

\begin{tabular}{|l|l|l|}
\hline Kelas & Sig. 2 tailed pre-test & Sig. 2 tailed post-test \\
\hline 4A & 0.537 & 0.074 \\
\hline 4B & 0.106 & 0.527 \\
\hline
\end{tabular}

Tabel 4. Tabulasi Hasil Uji Normalitas

Berdasarkan tabel 3, nilai Sig. 2 tailed data pada kelas 4A dan 4B lebih besar dari taraf signifikansi pada penelitian ini yaitu 0.05 , maka data pada kedua kelas berdistribusi normal. Sehingga akan dilanjutkan pengujian parametrik.

b) Uji Homogenitas

Untuk menentukan homogenitas variansi maka perlu diuji homogenitas. Data dengan varian homogen dari adalah data dengan nilai sig. lebih besar dari taraf signifikansi (Priyatno, 2008).

\begin{tabular}{ll|r|r|r|r}
\multicolumn{2}{c}{ Test of Hom ogeneity of Variances } \\
& $\begin{array}{l}\text { Levene Statistic } \\
\text { Nf1 }\end{array}$ & df2 & \multicolumn{1}{c}{ Sig. } \\
\hline \multirow{2}{*}{ Nilai } & 1.793 & 3 & 68 & .157 \\
\cline { 2 - 7 } & Based on Mean & 1.125 & 3 & 68 & .345 \\
\hline & $\begin{array}{l}\text { Based on Median } \\
\text { Based on Median and with }\end{array}$ \\
$\begin{array}{l}\text { adjusted df } \\
\text { Based on trimmed mean }\end{array}$ & 1.125 & 3 & 59.580 & .346 \\
\hline
\end{tabular}


Berdasarkan tabel 5, data dari kelas 4A dan kelas 4B, nilai Sig. 2 tailed data yaitu 0.157 lebih besar dari 0.05 (taraf signifikansi), maka variansi data homogen.

\section{c) Uji t}

Penelitian ini menggunakan independent sample $t$ test . Uji $\mathrm{t}$ dapat digunakan pada data parametrik. Dari uji normalitas dan homogenitas pada kelas 4A dan 4B, kedua data dikatakan normal dan homogen sehingga dapat dilakukan uji t pada keduanya untuk mengetahui apakah kemampuan awal dan akhir masing masing kelas memiliki perbedaan yang signifikan.

\begin{tabular}{|c|c|c|c|c|c|c|c|c|c|c|}
\hline \multicolumn{11}{|c|}{ Independent Samples test } \\
\hline & & & & & & Sig (2- & Mean & Std Error & $\begin{array}{r}95 \% \mathrm{Co} \\
\text { Interval of }\end{array}$ & $\begin{array}{l}\text { idence } \\
\text { ifference }\end{array}$ \\
\hline & & $\mathrm{F}$ & Sig. & $\mathrm{t}$ & df & tailed) & Differences & Differences & Lower & Upper \\
\hline \multirow[t]{2}{*}{ hasil } & $\begin{array}{l}\text { Equal variance } \\
\text { assumed }\end{array}$ & ,398 &, 532 & $\begin{array}{r}- \\
4,036\end{array}$ & 36 &, 000 & $-20,474$ & 5,072 & $-30,761$ & $-10,186$ \\
\hline & $\begin{array}{l}\text { Equal } \\
\text { variances not } \\
\text { assumed }\end{array}$ & & & 4,036 & 34,922 &, 000 & $-20,474$ & 5,072 & $-30,772$ & $-10,175$ \\
\hline
\end{tabular}

Tabel 6. Uji t pada Pre-test dan Post-test Kelas 4A

Apabila nilai Sig. (2 tailed) dibawah taraf signifikansi 0.05 maka antara nilai pre-test dan post-test pada kelas $4 \mathrm{~A}$ terdapat perbedaan nilai yang siginifikan. Pada tabel 6, nilai Sig. 2 Tailed adalah 0,000 maka antara nilai pretest dan post-test pada kelas 4A terdapat perbedaan siginifikan. Kemudian dilanjutkan dengan uji t untuk nilai pre-test dan post-test kelas 4B.

\begin{tabular}{lllllllllll}
\multicolumn{10}{c}{ Independent Samples test } \\
\hline
\end{tabular}


Tabel 7. Uji t pada Pre-test dan Post-test Kelas 4B

Pada tabel 7, nilai Sig. 2 Tailed adalah 0,013 maka nilai pre-test dan posttest kelas 4B memiliki perbedaan signifikan. Karena pada uji ini, kemampuan awal dan akhir kedua kelas sama sama signifikan perbedaannya, maka perlu dilakukan uji gain ternormalisai untuk mengetahui persentase keefektifan virtual classroom dan flip the teacher.

\section{b. Pengujian Hipotesis}

Uji t dan uji gain ternormalisasi diberlakukan pada pengujian ini karena terdapat 2 kelas yang masing masing menerima perlakuan yang berbeda, artinya masing masing kelompok perlu diuji persentase efektifitasnya dengan hipotesis sebagai berikut :

Hipotesis A :

Virtual classroom tidak memiliki efektivitas pada mata kuliah Chuukyu Bunpou pada Semester IV UHAMKA tahun ajaran 2019-2020

Hipotesis B :

Flip the Teacher tidak memiliki efektivitas pada mata kuliah Chuukyu Bunpou pada Semester IV UHAMKA tahun ajaran 2019-2020

Hipotesis C :

Virtual classroom memiliki efektivitas yang lebih tinggi dari Flip the teacher pada mata kuliah Chuukyu Bunpou pada Semester IV UHAMKA tahun ajaran 2019-2020

Hipotesis D :

Virtual classroom memiliki efektivitas yang lebih rendah dari Flip the teacher pada mata kuliah Chuukyu Bunpou pada Semester IV UHAMKA tahun ajaran 2019-2020

Hipotesis E : 
Virtual classroom memiliki efektivitas yang sama dengan Flip the teacher pada mata kuliah Chuukyu Bunpou pada Semester IV UHAMKA tahun ajaran 2019-2020

Pengujian hipotesis dilakukan dengan 2 tahap yaitu:

a) Uji t Nilai Gain Kelas 4A dan 4B

Uji ini berfungsi untuk menganalisis peningkatan hasil belajar (nilai gain) antara kelas 4A dan 4B apakah perbedaannya signifikan.

\begin{tabular}{|c|c|c|c|c|c|c|c|c|c|c|}
\hline \multicolumn{11}{|c|}{ Independent Samples test } \\
\hline & & & & & & Sig. (2- & Mean & Std. Error & $\begin{array}{r}95 \% \mathrm{Co} \\
\text { Interval of }\end{array}$ & $\begin{array}{l}\text { fidence } \\
\text { bifference }\end{array}$ \\
\hline & & $\mathrm{F}$ & Sig. & $t$ & df & tailed) & Differences & Differences & Lower & Upper \\
\hline \multirow[t]{5}{*}{ hasil } & Equal & & & & & & & & & \\
\hline & variance & ,952 & ,336 & 1,288 & 34 & 207 & 15,63672 & 12,14187 & $-9,03853$ & 40,31197 \\
\hline & assumed & & & & & & & & & \\
\hline & Equal & & & & & & & & & \\
\hline & variances not & & & 1,263 & 28,402 &, 217 & 15,63672 & 12,37759 & $-9,70147$ & 40,97491 \\
\hline
\end{tabular}

Tabel 8. Uji t Nilai Gain Kelas 4A dan 4B

Pada tabel 8, nilai Sig. 2 tailed hasil uji t nilai gain antara kelas 4A dan 4B adalah 0,207. Artinya nilai Sig. 2 tailed diatas taraf signifikansi. Maka, perbedaan antara nilai gain (nilai peningkatan hasil belajar) kelas 4A dan 4B tidak signifikan. Setelah mengetahui signifikansi perbedaan nilai gain kelas $4 \mathrm{~A}$ dan 4B, maka tahap selanjutnya adalah mengetahui persentase dan score untuk peningkatan kemampuan dari menggunakan virtual classroom dan flip the teacher.

b) Uji gain ternormalisasi

Menurut Sundayana, untuk menentukan nilai peningkatan hasil belajar sebelum dan sesudah diberikan treatment adalah menggunakan uji gain ternormalisasi (Sundayana, 2018). Sehingga kita dapat mengetahui efektifitas dari suatu metode pembelajaran yang diujikan menggunakan uji gain 
ternormalisasi. Uji gain dapat dilakukan jika data memiliki perbedaan kemampuan awal dan akhir. Untuk virtual classroom yang digunakan pada kelas eksperimen 1 telah menunjukkan adanya perbedaan antara kemampuan awal dan akhir, serta teknik flip the teacher yang digunakan pada kelas eksperimen 2 juga telah menunjukkan perbedaan antara kemampuan awal sebelum digunakan teknik ini dengan kemampuan akhir setelah digunakan teknik ini. Pengujian gain ternormalisasi menggunakan SPSS Statistics 25.

Untuk mengetahui besarnya peningkatan nilai antara sebelum treatment dan sesudah treatment, digunakan rumus gain ternormalisasi sebagai berikut (Sundayana, 2018) :

$$
\text { Gain ternormalisasi }(\mathrm{g})=\frac{\text { Score posttest }- \text { score pretest }}{\text { maximum score }- \text { score posttest }}
$$

Gambar 1. Rumus Gain Ternormalisasi

Berikut hasil pengujian dan analisis nilai gain ternormalisasi :

\begin{tabular}{lllll}
\hline & \multicolumn{2}{c}{ Descriptives } & & \\
\hline & kelas & & Statistic & Std. Error \\
\hline gain_persen & Kelas 4A & Mean & 49,5062 & 6,86725 \\
& & $95 \%$ Confidences Interval & Lower Bound & 35,0786 \\
& for Mean & Upper Bound & 63,9337 \\
& 5\% Trimmed Mean & 49,8629 \\
& Median & 45,8333 \\
& Variance & 896,022 \\
& Std. Deviation & 29,93363 \\
& Minimum & $-7,41$ \\
& Maximum & 100,00 \\
& Range & 107,41 \\
\hline
\end{tabular}




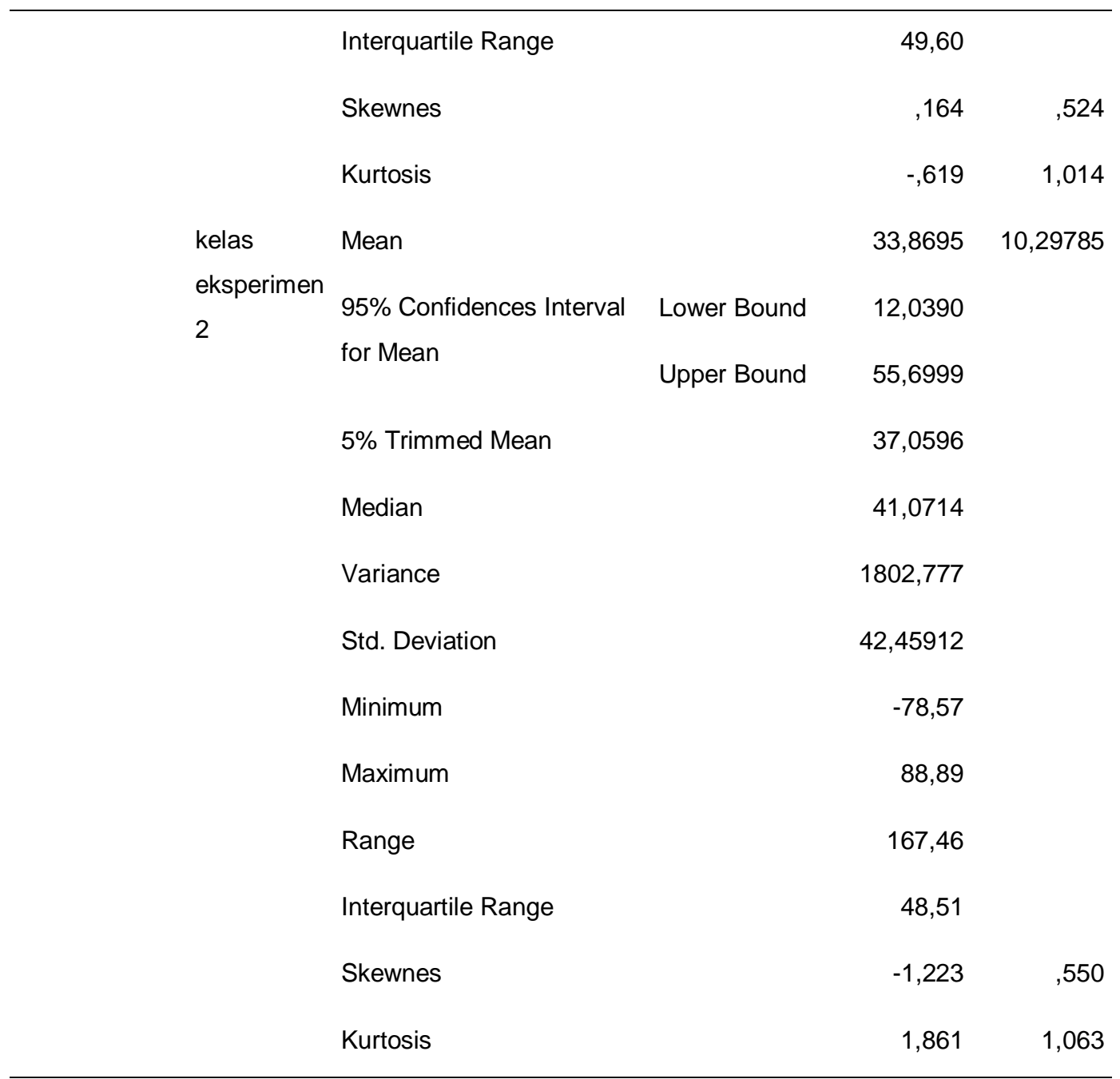

Tabel 9. Uji Gain Ternormalisasi

\begin{tabular}{lllll}
\hline & Nilai & Persentase & $\begin{array}{l}\text { Nilai } \\
\text { Minimum }\end{array}$ & $\begin{array}{l}\text { Nilai } \\
\text { Maksimum }\end{array}$ \\
\hline Kelas 4A & 0,49 & $49,50 \%$ & $-7,41$ & 100 \\
Kelas 4B & 0,34 & $33,86 \%$ & $-78,57$ & 88,89 \\
\hline
\end{tabular}

Tabel 10. Tabulasi Hasil Uji Gain Ternormalisasi 


\begin{tabular}{cc}
\hline Nillai Gain & Keterangan \\
\hline$-1,00<$ Nilai $<0,00$ & Menurun \\
Nilai $=0,00$ & Tetap \\
$0,00<$ Nilai $<0,30$ & Rendah \\
$0,30<$ Nilai $<0,70$ & Sedang \\
$0,70<$ Nilai $<1,00$ & Tinggi \\
\hline
\end{tabular}

Tabel 11. Interpretasi Nilai Gain Ternormalisasi (Sundayana, 2018)

Dari hasil pengujian uji gain ternormalisasi pada nilai pre-test dan posttest kelas 4A dan 4B, didapatkan nilai gain untuk kelas 4A yang menggunakan virtual classroom sebesar 0,49, sedangkan kelas $4 \mathrm{~B}$ dengan penerapan flip the teacher didapatkan nilai gain sebesar 0,34 sehingga keduanya memiliki efektifitas yang tergolong sedang juga. Untuk membandingkan kefektifitas antara virtual classroom dan flip the teacher dapat kita lihat dari persentase gain. Persentase gain pada virtual classroom pada kelas eksperimen 1 yaitu 49,50\% sedangkan flip the teacher pada kelas eksperimen 2 memiliki persentase gain 33,86\% artinya meskipun keduanya tidak memiliki perbedaan signifikan pada peningkatan hasil belajar namun persentase efektifitas virtual classroom lebih besar daripada flip the teacher, dan keduanya memiliki tingkat efektifitas yang sama yaitu sedang. Maka pada pengujian hipotesis ini, hipotesis C diterima sehingga virtual classroom memiliki efektivitas yang lebih tinggi dari flip the teacher dalam meningkatkan hasil belajar pada mata kuliah chuukyu bunpou pada Semester IV Universitas Muhammadiyah Prof. DR. HAMKA tahun ajaran 2019-2020.

\section{KESIMPULAN}

Sebelum dilakukan treatment menggunakan virtual classroom dan flip the teacher pada flipped classroom, nilai pre-test kelas $4 \mathrm{~A}$ dan $4 \mathrm{~B}$ rata-rata dibawah 70. Namun setelah dilakukan treatment menggunakan virtual classroom dan flip the teacher baik kelas 4A maupun kelas 4B mengalami 
peningkatan hasil belajar, untuk kelas 4A dengan menggunakan virtual classroom sebesar 49,5\% sedangkan kelas 4B sekitar 33\%. Artinya penggunaan virtual classroom dan flip the teacher sama sama efektif dalam peningkatan hasil belajar pada mata kuliah chuиkyuu bunpou. namun persentase keefektifitasan virtual classroom lebih tinggi bahkan mendekati tingkat efektifitas tinggi daripada flip the teacher. Sehingga dapat disimpulkan bahwa dalam flipped classroom, virtual classroom dan flip the teacher meski memiliki tingkat efektivitas yang sama namun virtual classroom lebih efektif karena presentase efektifitasnya lebih tinggi dalam meningkatkan hasil belajar daripada flip the teacher pada mata kuliah chuukyuu bunpou pada mahasiswa semester IV Pendidikan Bahasa Jepang UHAMKA tahun 2019-2020.

\section{REFERENSI}

Agustin, Y. (2015). Penguasaan tata bahasa dan berpikir logik serta kemampuan menulis artikel ilmiah. Faktor Jurnal Ilmiah Kependidikan, 2(2), 123-132.

Amornchai, P., Songkhla, J. N., \& Sujiva, S. (2015). An argument performance task in a virtual classroom for enhancing graduate students' analytical reasoning. Procedia - Social and Behavioral Sciences, 174, 1031-1035. https://doi.org/10.1016/j.sbspro.2015.01.790

Andrews, R., Torgerson, C., Beverton, S., Freeman, A., Locke, T., Low, G., ... Zhu, D. (2006). The effect of grammar teaching on writing development. British Educational Research Journal, 32(1), 39-55. https://doi.org/10.1080/01411920500401997

Comfort, P., \& James McMahon, J. (2014). The effect of peer tutoring on academic achievement. Journal of Applied Research in Higher Education, 6(1), 168-175. https://doi.org/10.1108/JARHE-06-2012-0017

Graziano, K. J. (2017). Peer teaching in a flipped teacher education classroom. TechTrends, 61(2), 121-129. https://doi.org/10.1007/s11528-0160077-9

Ismail, S. S., \& Abdulla, S. A. (2019). Virtual flipped classroom: New teaching model to grant the learners knowledge and motivation. Journal of Technology and Science Education, 9(2), 168-183. 
https://doi.org/10.3926/jotse.478

Kapil, Y., \& Malini, S. (2018). Peer tutoring an instructional strategy: A systematic approach. Scholarly Research Journal for Humanity Science \& English Language, 6(27).

Lai, C. C., \& Kritsonis, W. A. (2006). The advantages and disadvantages of computer technology in second language acquisition. Online Submission, $3(1)$.

Milman, N. (2012). The flipped classroom strategy: What is it and how can it best be used? Distance Learning, 9, 85-87.

Patten, K. B., \& Craig, D. V. (2007). iPods and English-language learners: A great combination. TEACHER LIBRARIAN-SEATTLE-, 34(5), 40.

Pavanelli, R. (2018). The flipped classroom : A mixed methods study of academic performance and student perception in EAP writing context 4205 Bonaventure Blvd. 5(2), 16-26.

https://doi.org/10.30845/ijll.v5n2p3

Priyatno, D. (2008). Mandiri belajar SPSS (untuk analisis dan uji statistik). MediaKom.

Rindaningsih, I. (2018). Efektifitas model flipped classroom dalam mata kuliah perencanaan pembelajaran prodi S1 PGMI UMSIDA. Proceedings of the ICECRS, 1(3), 51-60. https://doi.org/10.21070/picecrs.v1i3.1380

Rochmah, E., \& Majid, N. W. A. (2018). Membangun virtual classroom melalui social learning networks (SLNS). Premiere Educandum: Jurnal Pendidikan Dasar Dan Pembelajaran, 8(1), 15. https://doi.org/10.25273/pe.v8i1.1832

Septianingsih, D. A., \& Karnawati, R. A. (2019). Efektivitas quantum learning melalui teknik clustering dalam pembelajaran shochuukyu sakubun untuk meningkatkan kemampuan menulis pada semester IV program studi sastra Jepang STBA JIA. 02(01), 94-105.

Sojayapan, C., \& Khlaisang, J. (2018). The effect of a flipped classroom with online group investigation on students' team learning ability. Kasetsart Journal of Social Sciences, 4-9. https://doi.org/10.1016/j.kjss.2018.02.003

Sundayana, R. (2018). Statistika penelitian pendidikan. Penerbit Alfabeta. 